\title{
食品中の脂質の酸化生成物による風味変化 Changes of Flavors by Lipid Oxidation in Foods
}

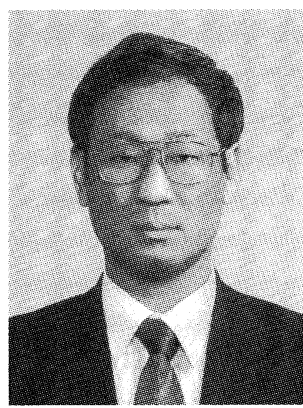

\author{
高村仁知 ${ }^{1)}$,2) \\ 1) 奈良女子大学生活環境学部食物栄養学科 \\ 2) 奈良女子大学共生科学研究センター \\ T630-8506 \\ 奈良市北魚屋西町 \\ Hitoshi TAKAMURA ${ }^{1), 2)}$ \\ ${ }^{1)}$ Department of Food Science and Nutrition, Nara \\ Women's University \\ ${ }^{2}$ Kyousei Science Center for Life and Nature, Nara \\ Women's University \\ 1), 2)Kitauoya-nishimachi, Nara, 630-8506, JAPAN
}

論文要旨：脂質に含まれる多価不飽和脂肪酸は構造的に酸化されやすく，食品においては調理加工や保存 の過程などで酸化をうける。その結果，生じた脂質酸化生成物には食品の風味を損なう，毒性を有するなど， 食品の品質に悪影響をもたらすものがある。大豆においては，リノール酸がリポキシゲナーゼによって酸化 されて生成するリノール酸 13 S-ヒドロペルオキシドから豆臭の主成分であるへキサナールが生ずる。大豆 種子に存在する 3 種のリポキシゲナーゼアイソザイムのうち，L-2 アイソザイムがヘキサナール生成に最も 寄与し，L-3 アイソザイムは逆にヘキサナール生成に寄与せず，逆にへキサナール生成を抑制する。一方， 魚に扔いては, 従来, トリメチルアミンが魚臭の主成分であるとされてきたが，イコサペンタエン酸やドコ サへキサエン酸などの酸化劣化に由来する多くのカルボニル化合物が存在すること，これらの化合物はさま ざまなにおいを有しており，これらのにおいが相まって魚臭となっていることが明らかとなった。

\begin{abstract}
Polyunsaturated acids in lipids are easy to be oxidized during preservation, processing, and cooking of foods. Some lipid oxidation products deteriorate food quality. In soybean, hexanal, the main beany flavor compound, is produced via the oxidation of linoleic acid by lipoxygenase. Among three isozymes in soybean seeds, L-2 isozyme mainly contributes hexanal formation, but L-3 suppresses its formation. In fish, trimethylamine has been thought to be the main fishy compound. However, many carbonyl compounds, which were produced by oxidation of icosapentaenoic and docosahexaenoic acids, have various kinds of flavors and contributes fishy flavor rather than trimethylamine.
\end{abstract}

Key words: lipid oxidation, beany flavor, fishy flavor, odor, carbonyl compounds, polyunsaturated fatty acid

\section{1 はじめに}

食品中の脂質は，栄養学的にはエネルギー源として， あるいはリノール酸などの必須脂肪酸の供給源として重 要である。また，食品学的には食品の食感や物性に大き く寄与している。このように，脂質は人間が生きていく 上で，さらに食生活を楽しむ上で久かせない存在であ る。

さて, 脂質の物理的性質 (融点, 粘度など), 化学的

連絡者：高村仁知

E-mail : takamura@cc.nara-wu.ac.jp
性質（酸化安定性など)，生物学的性質（栄養性，生理 的機能など）は，脂質に含まれる脂肪酸の種類によって 決まる。脂質の性質を決める大きな要因は脂肪酸の不飽 和度である。二重結合を 2 つ以上含む多価不飽和脂肪酸 はさらに n-6 系と n-3 系に分類されるが，n-6 系多価不 飽和脂肪酸であるリノール酸（18：2）や n-3 系多価不 飽和脂肪酸である $\alpha-$ リノレン酸 $(18 ： 3)$ は必須脂肪酸 と呼ばれ，人間を含む動物が生きていく上で食物から摂 取しなくてはならない。

しかし，リノール酸などの多価不飽和脂肪酸は化学構 造的に酸化されやすい。食品においては, 調理加工や保 
存の過程などで酸化をうける。その結果, 脂質過酸化物 が生成する。脂質酸化はリポキシゲナーゼなどの酵素反 応により，あるいは自動酸化などの非酵素的反応により 進行する。また, これと並行して, 重合, 開裂, 転位等 によりカルボニル化合物（アルデヒド，ケトン）などの 極性化合物や重合物などさまざまな酸化二次生成物が生 ずる。これらの脂質酸化生成物には食品の風味を損な う, 毒性を有するなど, 食品の品質に悪影響をもたらす ものがある。

筆者らはこれまで, 食品の脂質劣化およびこれによる 風味変化について明らかにしてきた。ここでは，それら の研究の一端を紹介する。

\section{2 大豆における脂質劣化と風味変化}

まず，大豆に打けるリノール酸の酵素的酸化によるリ ノール酸ヒドロペルオキシドの生成, および豆臭の主成 分であるへキサナールの生成などについて述べる。大豆 は，良質のタンパク質を豊富に含むため，日本やアジア の国々で古くから豆腐などの伝統的大豆食品として利用 されてきた。現代では大豆から油脂を抽出した後に残る タンパク質を有効利用した大豆タンパク質食品が広く利 用されている。また，抽出した油脂は大豆油として世界 中で広く利用されている。大豆油には必須脂肪酸である

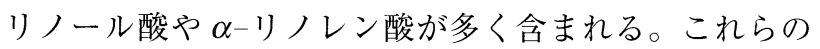
多価不飽和脂肪酸は酸化されやすい。天ぷらに用いると 香ばしい香りのもとになるが, 大豆食品では青臭い不快 臭 (豆臭) の原因となる。従って, 大豆食品の需要拡大 のためには，豆臭の生成抑制が重要である。

豆臭の原因物質のうち, 最も重要な成分は閾值が低 く, 生成量の多いへキサナールである。このへキサナー ルは, 大豆に存在する脂質過酸化酵素リポキシゲナーゼ がリノール酸を酸化することにより，リノール酸 $13 \mathrm{~S}-$ ヒドロペルオキシドを経て生成する。リノール酸ヒドロ ペルオキシドには, OOH 基の位置によって 2 種類の位 置異性体（9-, 13-）が， $\mathrm{OOH}$ 基の向きによってそれぞ れ 2 種類の光学異性体 (R-, S-) が存在するが, $13 \mathrm{~S}-$ ヒ
ドロペルオキシドのみがヒドロペルオキシドリアーゼに より開裂し，ヘキサナールとなる。

大豆種子には 3 つのリポキシゲナーゼアイソザイム L-1，L-2，L-3 が存在し，それぞれ性質が異なる。これ らのうち，L-2アイソザイムがへキサナール生成に最も寄 与していることが的場らによって明らかになっている1)。

本研究では，これらのアイソザイムを 1 種類のみ含む 変異大豆拉よびいずれも含まない変異大豆を用いて， キサナール生成を調べたところ，L-3 アイソザイムのみ を含む変異大豆で生成量が最も低いことを見いだした $($ Table 1) 2)。このことから，L-3 アイソザイムはへキサ ナール生成に寄与せず，逆にヘキサナール生成を抑制す ることが明らかとなった。すなわち，Fig. 1 に示すよう に，L-3 アイソザイムはヒドロペルオキシドリアーゼの

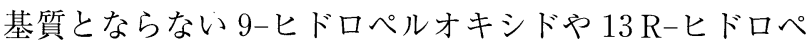
ルオキシドを生成する ${ }^{3)}$ 。また，空気中の酸素付加を伴

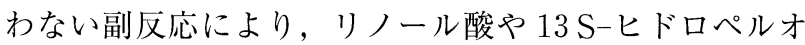
キシドを他の物質に変換してしまうう)。これらの反応に より，L-3アイソザイムはへキサナール生成を抑制する と考えられる。従って，L-3 アイソザイムのみを有する 大豆を利用すれば，豆臭の少ない大豆製品を作ることが できるようになり，大豆製品の需要拡大が期待できる。 また，大豆中にはアルコールデヒドロゲナーゼが存在す るため，これを利用してへキサナールを減少させること もできる゙)。

一方，大豆に抏ては，へキサナール以外のカルボニ ル化合物も生成する。水中のカルボニル化合物の定量法 について開発し5)，豆乳中の総カルボニル量およびへキ サナール量を測定したところ, 総カルボニル量に占める ヘキサナールの割合は，基質となるリノール酸を添加し ない場合約 1\%，リノール酸を添加しても10\%未満で あった (Table 2) ${ }^{6)}$ 。このことから，大豆における豆臭 には，ヘキサナールが大きく寄与しているものの，他の カルボニル化合物の寄与も無視できないと考えられる。

な押，大豆に押いては，リポキシゲナーゼ産物から毒 性アルデヒドであるヒドロキシアルケナールが生成する

Table 1 リポキシゲナーゼ久損大豆におけるへキサナール生成 ${ }^{2)}$

\begin{tabular}{lcc}
\hline \multirow{2}{*}{ 大豆 } & \multicolumn{2}{c}{ ヘキサナール生成量 } \\
\cline { 2 - 3 } & \multicolumn{2}{c}{$(\mathrm{nmol} / \mathrm{mg}$ タンパク質 $)$} \\
& 1.34 & 2.03 \\
通常 & 0.14 & 1.41 \\
全欠損 & 0.15 & 3.56 \\
$\mathrm{~L}-1$ のみ含有 & 1.86 & 6.31 \\
$\mathrm{~L}-2$ のみ無添加 & $0.2 \mathrm{mM}$ クノール酸添加 \\
$\mathrm{L}-3$ のみ含有 & 0.14 & 0.37 \\
\hline
\end{tabular}



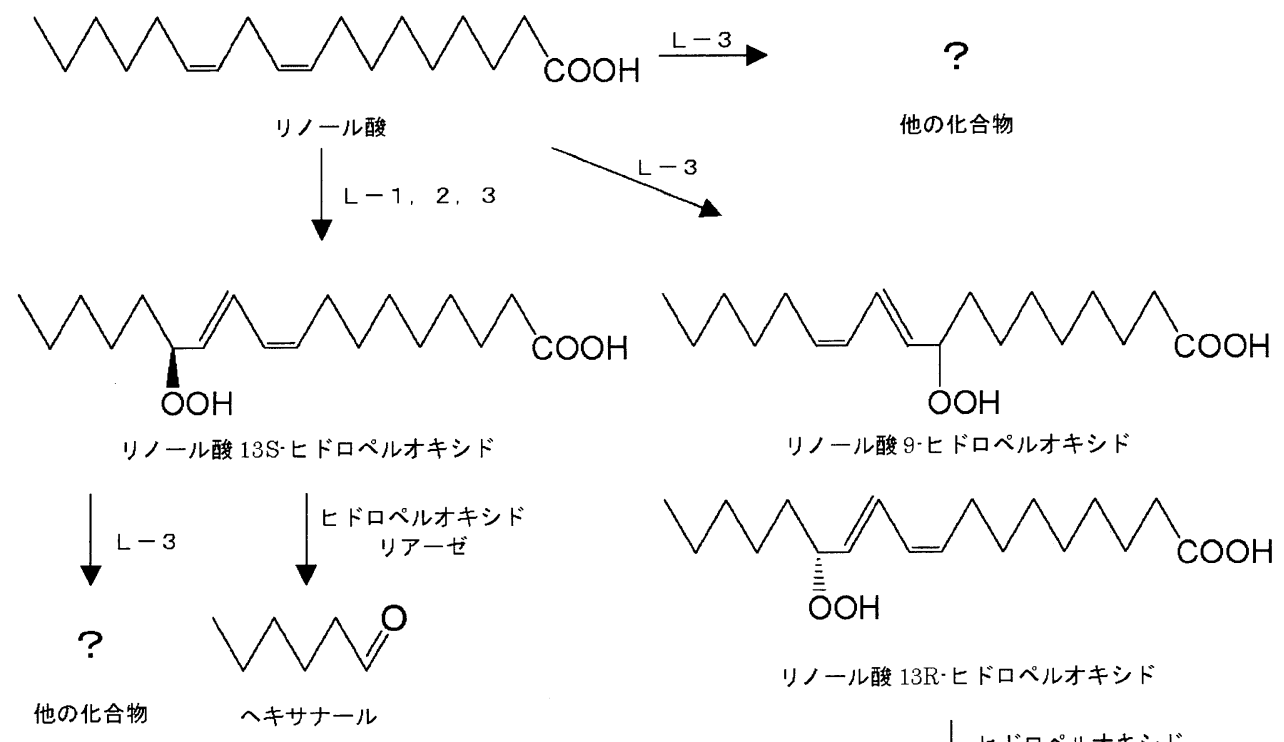

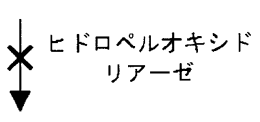

ヘキサナールは生成しない

Fig. 1 ヘキサナール生成におけるリポキシゲナーゼアイソザイムの役割

Table 2 大豆におけるへキサナール生成量が総カルボニル量に占める割合 ${ }^{6}$

\begin{tabular}{|c|c|c|c|}
\hline \multicolumn{2}{|c|}{ ヘキサナール生成量 } & \multicolumn{2}{|c|}{ 総カルボニル量 } \\
\hline リノール酸無添加 & $0.2 \mathrm{mM}$ リノール酸添加 & リノール酸無添加 & $0.2 \mathrm{mM}$ リノール酸添加 \\
\hline \multicolumn{4}{|c|}{ (nmol/mg タンパク質) } \\
\hline $\begin{array}{c}0.45 \\
(1.3 \%)\end{array}$ & $\begin{array}{c}3.55 \\
(9.1 \%)\end{array}$ & 32.7 & 38.8 \\
\hline
\end{tabular}

かっこ内は総カルボニル量に占める割合。

経路が存在する7)。このように，大豆リポキシゲナーゼ による脂質酸化に由来する化合物は，嗜好性のみならず 安全性にも影響を及ぼすため，リポキシゲナーゼ欠損大 豆の利用が有用であると考えられる。

\section{3 魚における脂質劣化と風味変化}

次に，魚における多価不飽和脂肪酸の酸化による魚臭 の生成について述べる。魚，特に海産魚の脂質には，不 飽和度の高いイコサペンタエン酸（EPA, 20:5）やドコ サヘキサエン酸（DHA, 22：6）など，n-3 系の多価不飽 和脂肪酸が多く含まれている。イコサペンタエン酸から 生成するエイコサノイドは, n-6 系の多価不飽和脂肪酸 であるアラキドン酸（20：4）から生成するエイコサノ イドに対して拮抗的に作用するため，血小板凝集抑制作 用，アレルギー抑制作用などを有する。従って，魚を通 してこれらの脂肪酸を摂取することは健康増進に有効で あると考えられている。

さて，魚は強い生臭いにおい（魚臭）を有することが
ある。この魚臭の主成分はアミン化合物とされている。 特に, 魚肉中に存在するトリメチルアミンオキシドが魚 の死後に微生物の作用によって分解されて生ずるトリメ チルアミンがいわゆる魚臭いに拈いを有する。しかし， 著者らの研究では, トリメチルアミンよりも, むしろ脂 質劣化に由来する成分が魚臭に寄与することが明らかと なった ${ }^{8,9)}$ 。

Table 3 イワシ揮発性成分中に含まれるトリメチルアミン量 と $\mathrm{pH}$ との関係 ${ }^{9}$

\begin{tabular}{ccc}
\hline \multirow{2}{*}{$\mathrm{pH}$} & \multicolumn{2}{c}{ トリメチルアミン } \\
\cline { 2 - 3 } & 生成量 $(\mathrm{ppm})$ & におい強度 \\
\hline 6.2 & $\mathrm{ND}$ & $\mathrm{ND}$ \\
7 & $0.21 \pm 0.17$ & $\mathrm{ND}$ \\
8 & $0.86 \pm 0.55$ & $\mathrm{ND}$ \\
9 & $2.42 \pm 1.50$ & \pm \\
10 & $6.37 \pm 2.67$ & + \\
11 & $23.95 \pm 10.14$ & ++ \\
12 & $29.55 \pm 8.75$ & ++ \\
\hline
\end{tabular}


イワシに緩衝液を加えて磨砕し, 密封バイアルに入れ てヘッドスペースガスを固相微量抽出（SPME）法で捕 集し，ガスクロマトグラフィー（GC）で分析したとこ ろ，イワシそのものの $\mathrm{pH}$ (6.2) 〜中性付近ではトリメ
チルアミンはほとんど検出されず， $\mathrm{pH}$ を上げることで 検出された（Table 3）。このことは，一般的な食品の $\mathrm{pH}$ （酸性〜中性）ではトリメチルアミンの生成は見ら れても，においとしては感知できないことを示唆してい

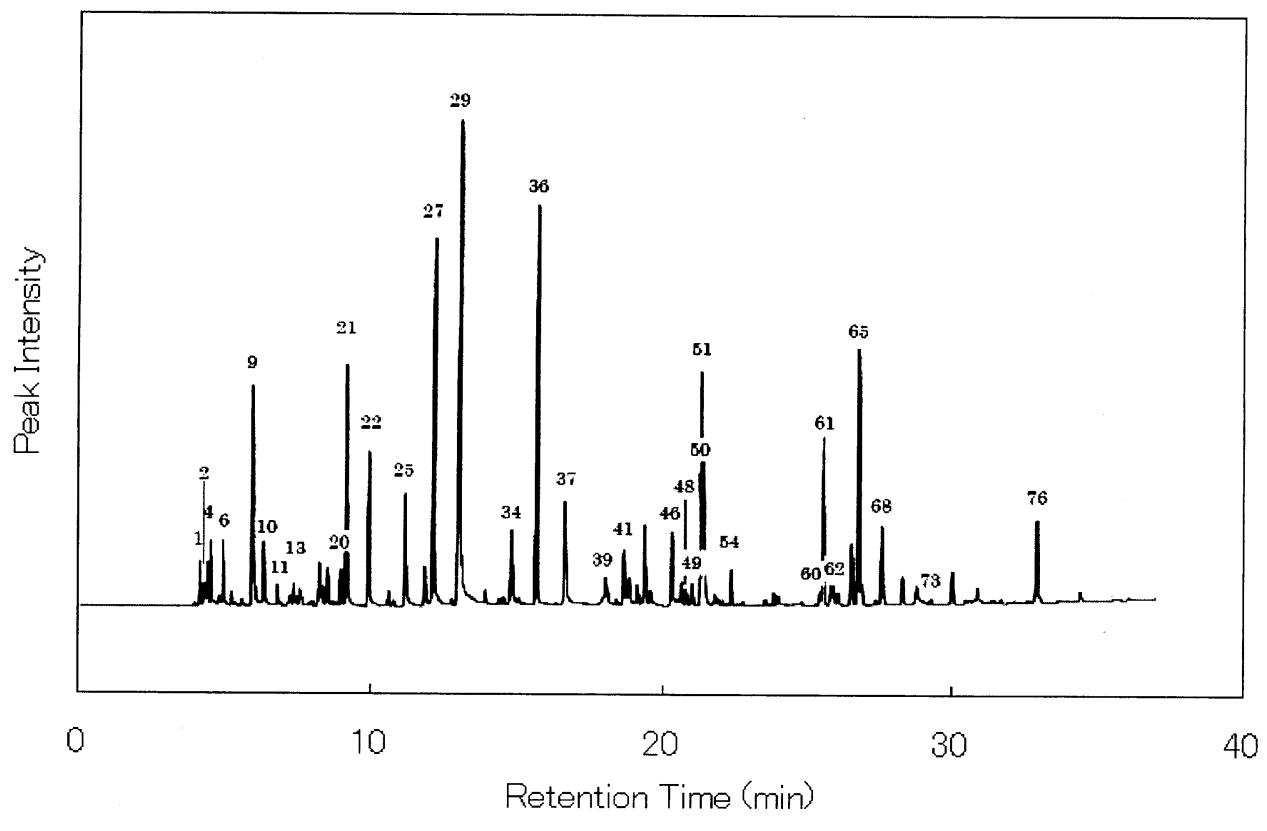

Fig. 2 イワシ揮発性成分の GCクロマトグラム ${ }^{9}$

イワシ磨砕物から生成する揮発性成分を固相微量抽出（SPME）法で捕集し，揮発性成分の同定を GC-MS で, においの同定を GC-オルファクトメトリー（においかぎ法）で行った。ピーク番号は Table 4 に対応する。

Table 4 イワシ揮発性成分の同定およびにおい9

ピーク番号は Fig. 2のクロマトグラムに対応する。ーはクロマトグラム上では明確に得られなかったピーク。

\begin{tabular}{|c|c|c|c|c|c|c|c|}
\hline $\begin{array}{c}\text { ピーク } \\
\text { 番号 }\end{array}$ & $\begin{array}{l}\text { 保持 } \\
\text { 時間 } \\
\text { (分) }\end{array}$ & 化合物名 & におい & $\begin{array}{c}\text { ピーク } \\
\text { 番号 }\end{array}$ & $\begin{array}{l}\text { 保持 } \\
\text { 時間 } \\
\text { (分) }\end{array}$ & 化合物名 & におい \\
\hline 2 & 4.2 & 2-pentene & gas, chemical, paint & - & 20.7 & (unknown) & melon, sweet \\
\hline - & 4.6 & (unknown) & enteruria, sulfide & - & 21.0 & (unknown) & sweet \\
\hline 9 & 5.6 & 1-propanal & alcoholic & - & 21.7 & (unknown) & paper \\
\hline- & 8.0 & (unknown) & paint, chemical & - & 22.2 & (unknown) & roasted \\
\hline- & 9.1 & 2,3-butanedione & caramel, rotten & - & 22.4 & (unknown) & sweet \\
\hline 22 & 9.3 & pentanal & green & - & 22.9 & (unknown) & metalic \\
\hline- & 9.4 & (unknown) & gas & - & 23.2 & (unknown) & bloody \\
\hline- & 10.1 & (unknown) & paint, chemical & - & 23.4 & (unknown) & paper \\
\hline 25 & 10.5 & 1-pentene-3-one & paint, chemical & 60 & 25.4 & $2 \mathrm{E}-$ octenal & aromatic, oxidized oil \\
\hline 27 & 11.5 & 2,3-pentanedione & caramel, rotten & - & 25.7 & (unknown) & paper \\
\hline 29 & 12.3 & hexanal & green & - & 25.9 & (unknown) & burdock \\
\hline- & 12.4 & (unknown) & coffee, allium & - & 26.6 & methional & potato \\
\hline- & 13.1 & (unknown) & paint, chemical & - & 27.0 & (unknown) & metalic \\
\hline 34 & 14.3 & $2 \mathrm{E}$-pentanal & green & 68 & 27.9 & 2E, 4E-heptadienal & aromatic, oxidized oil \\
\hline- & 14.5 & (unknown) & green & - & 29.3 & (unknown) & water melon \\
\hline- & 14.8 & (unknown) & potato & 73 & 31.1 & $2 \mathrm{E}, 6 \mathrm{Z}$-octadienal & insect \\
\hline 37 & 16.0 & heptanal & citrus & - & 31.3 & (unknown) & melon, sweet \\
\hline- & 16.5 & (unknown) & bloody & - & 35.0 & (unknown) & aromatic, oxidized oil \\
\hline 41 & 18.3 & 4Z-heptanal & ocean & - & 35.5 & (unknown) & dried fish, dustcloth \\
\hline- & 19.4 & (unknown) & shiitake-mushroom & - & 37.8 & (unknown) & roasted \\
\hline 46 & 20.0 & octanal & citrus & - & 39.0 & (unknown) & aromatic, oxidized oil \\
\hline 48 & 20.5 & 1-octene-3-one & shiitake-mushroom & & & & \\
\hline
\end{tabular}


る。

アミノ化合物以外のにおい成分としては，脂質劣化に 由来するカルボニル化合物などが考えられる。そこで, 同様の方法でイワシ磨砕物のヘッドスペースガスを SPME 法で捕捉し，GC-質量分析計（MS）で同定, GC-オルファクトメトリーでにおいかぎ分析を行った (Fig. 2, Table 4)。その結果, 脂質劣化に由来する多く のカルボニル化合物が存在すること, これらの化合物は さまざまなにおいを有しており，これらのにおいが相 まって魚臭となっていることが明らかとなった。

このように, 魚臭には, 脂質由来化合物が大きく寄与 していることから, 魚の調理加工の際に魚臭の生成を抑 えるには，脂質の劣化を抑制することが必要であると考 えられる。

\section{4 おわりに}

ここで述べた以外の食品においても，例えば，米の古 米臭やトマト, キュウリなどの青臭みにもリポキシゲ ナーゼ生成物が関与しているなど, 脂質の酸化は食品の 風味に大きな影響を与えている。筆者らの研究室ではこ れらの研究を元に, 現在, 調理加工過程における風味変
化と抗酸化成分との関係についてさらに研究を進めてい る。

\section{文献}

1) T. Matoba, H. Hidaka, H. Narita, K. Kitamura, N. Kaizuma \& M. Kito, J. Agric. Food Chem., 33, 852-5 (1985).

2) H. Takamura, K. Kitamura \& M. Kito, FEBS Lett., 292, 42-4 (1991).

3) H.W. Gardner, Biochim. Biophys. Acta, 1084, 221-39 (1991).

4) N. Yukawa, Y. Takahashi, T. Fujimura, K. Hasegawa, H. Takamura \& T. Matoba, J. Home Econ. Jpn., 43, 193-8 (1992).

5) N. Yukawa, H. Takamura \& T. Matoba, J. Am. Oil Chem. Soc., 70, 881-4 (1993).

6) N. Yukawa, H. Takamura, K. Kitamura \& T. Matoba, Biosci.Biotech. Biochem., 59, 723-4 (1995).

7) H. Takamura, H.W. Gardner, Biochim. Biophys. Acta, 1303, 83-91 (1996).

8) M.A. Mansur, A. Bhadra, H. Takamura, T. Matoba, Fish. Sci., 69, 864-6 (2003).

9) N. Ganeko, M. Shoda, I. Hirohara, A. Bhadra, T. Ishida, H. Matsuda, H. Takamura \& T. Matoba, J. Food Sci., submitted (2007). 